\title{
Article \\ Study on Land Consolidation Zoning in Hubei Province Based on the Coupling of Neural Network and Cluster Analysis
}

\author{
Pengnan Xiao ${ }^{1, \dagger}$, Chong Zhao ${ }^{2,+}$, Yong Zhou ${ }^{1, *}$, Haoyu Feng ${ }^{1}$, Xigui Li ${ }^{3}$ and Jinhui Jiang ${ }^{4}$ \\ 1 The College of Urban \& Environmental Sciences, Central China Normal University, Wuhan 430079, China; \\ maikedang@mails.ccnu.edu.cn (P.X.); hs2017122372@mails.ccnu.edu.cn (H.F.) \\ 2 School of Chemistry and Environmental Engineering, Wuhan Polytechnic University, Wuhan 430023, China; \\ zhaochong426@mail.ccnu.edu.cn \\ 3 College of Landscape Architecture and Art Design, Hunan Agricultural University, Changsha 410128, China; \\ lixigui128@hunau.edu.cn \\ 4 School of Life Sciences, Central China Normal University, Wuhan 430079, China; jiang_jh@ccnu.edu.cn \\ * Correspondence: yzhou@mail.ccnu.edu.cn \\ + Pengnan Xiao and Chong Zhao contributed equally to this work.
}

check for updates

Citation: Xiao, P.; Zhao, C.; Zhou, Y.; Feng, H.; Li, X.; Jiang, J. Study on Land Consolidation Zoning in Hubei Province Based on the Coupling of Neural Network and Cluster Analysis. Land 2021, 10, 756. https:// doi.org/10.3390/land10070756

Academic Editor: Hualou Long

Received: 30 June 2021

Accepted: 16 July 2021

Published: 19 July 2021

Publisher's Note: MDPI stays neutral with regard to jurisdictional claims in published maps and institutional affiliations.

Copyright: (c) 2021 by the authors. Licensee MDPI, Basel, Switzerland. This article is an open access article distributed under the terms and conditions of the Creative Commons Attribution (CC BY) license (https:/ / creativecommons.org/licenses/by/ $4.0 /)$.
Abstract: Land consolidation zoning is the basis of land reclamation planning and provides a precondition for land management work. Zoning is beneficial to scientific decision-making regarding the use of cultivated land resources, and helps to ensure the quality and production level of cultivated land. Hence, land consolidation zoning is of national significance in terms of safeguarding food security. In this paper, an indicator system for land evaluation and zoning is described based on indicators of natural ecological conditions, socioeconomic conditions, land-use conditions, and the land consolidation potential of Hubei province. The application of self-organizing maps and Hierarchical clustering results in 11 and 12 categories, respectively. After comparing and adjusting these results according to the real situation and key points in the land consolidation of each zone, seven integrated categories are determined. Finally, the land consolidation zoning scheme for these seven integrated partitions is shown to be suitable for Hubei province and in line with the real situation. The proposed scheme offers support for land remediation in a coordinated and orderly way, and provides a scientific basis for improving land utilization efficiency and grain production capacity in Hubei province.

Keywords: self-organizing feature mapping; hierarchical clustering; land consolidation; zoning

\section{Introduction}

Land consolidation, referring to production practices of land adjustment and arrangement, is a systematic project involving engineering and technology, economy and law, and administration and management [1]. An understanding of land consolidation is vital in any research on the rationality of land arrangement and use. As a further step, land consolidation clarifies the key points in regional remediation to ensure the best use of resources based on natural conditions, economic and social conditions, land use conditions, and ecological conditions [2].

Land consolidation zoning research in China has mainly focused on investigations into different objects with different spatial scales [3-14]. According to early reports, land consolidation zoning can be applied at national [5,13,15], regional [16], and landscape scales [9,11-13] and to rural and urban objects $[1,15,17]$. These early reports used many analysis methods, such as fuzzy clustering [18] and constellation clustering [19]. In recent years, land consolidation zoning research in other countries has mainly focused on three areas: landscape ecology [20-23], evaluation of land consolidation [24-27], and the relationships among land consolidation, agriculture, and rural development $[26,28,29]$.

Although both theoretical and empirical studies have reported significant results, various deficiencies and limitations still require improvement. First, the theoretical basis of 
land consolidation zoning should be enhanced, as there has been relatively little research on this topic. Moreover, most early research was empirical, especially in China. This can be supportive in arranging the regional land consolidation zoning, but is not helpful in improving related theories. Therefore, a systematic framework for these theories is yet to be developed and improved. Second, there are always problems in the selection of evaluation indicators. Multiple indicators are usually selected, but they are not always related to current policies for national and regional development. In other words, these indicators do not reflect local characteristics. Finally, little attention has been paid to the analysis methods used in land consolidation zoning research. However, the analysis technique is clearly of great importance in such research. Hierarchical clustering, constellation clustering, and the overlay method are most often used, but further analysis methods should be explored to enhance the results.

In this study, Self-organizing feature maps (SOMs) and Hierarchical clustering are applied to land consolidation zoning in Hubei province with complex terrain, China, at the provincial scale. Indicators with local characteristics are selected, and the results of the two analysis methods are compared. Regions placed in different zones by the two methods are carefully analyzed, and an optimized scheme is formed. This scheme can be considered a reference for future land consolidation programs in Hubei province.

\section{Materials and Methods}

\subsection{Data Resource and Processing}

Most of the data in this paper were collected from the 2015 China County Yearbook, 2015 City (District) Statistical Yearbooks of Hubei Provinces, and 2015 Land Change Survey Data of Hubei Province (Department of Land Resources, Hubei Province, 2016). Other data were collected from the survey of land consolidation potential conducted for the Land Consolidation Plans in Hubei Province (2015-2020). This paper uses the following formula for data standardization.

$$
x_{i j}^{\prime}=\frac{x_{i j}-\min \left(x_{j}\right)}{\max \left(x_{j}\right)-\min \left(x_{j}\right)} \quad(\mathrm{i}=1,2, \ldots \mathrm{m} ; \mathrm{j}=1,2, \ldots, \mathrm{n})
$$

where: $x_{i j}$ and $x_{i j}^{\prime}$ respectively represents the values of the $\mathrm{j}$-th index of the $\mathrm{i}$-th sample before and after standardization; $\max \left(x_{j}\right)$ and $\min \left(x_{j}\right)$, respectively, represents the maximum and minimum of the $j$-th index.

\subsection{Study Area}

Hubei province is located in central China, $108^{\circ} 21^{\prime} 142^{\prime \prime} \sim 116^{\circ} 07^{\prime} 50^{\prime \prime}$ east longitude and $29^{\circ} 01^{\prime} 53^{\prime \prime} \sim 33^{\circ} 06^{\prime} 47^{\prime \prime}$ north latitude, covering an area of $1.86105 \mathrm{~km}^{2}$. The terrain of Hubei province is generally surrounded by mountains in the east, west, and north, and the middle is low and flat. It is slightly open to the south as an incomplete basin. Hubei province has various geomorphic types, and it is also available in mountainous, hilly, gangland, and plain. Hubei province is located in the subtropical zone, in the typical monsoon region. Except for the high mountain areas, most areas of Hubei province have subtropical monsoon humid climate with abundant light energy, abundant heat, long frost-free period, abundant rainfall, and hot rain in the same season. The distribution of precipitation has obvious seasonal variation, which is the most in summer and the least in winter. Hubei is known as "a province of thousands of lakes", and the lakes are mainly distributed in Jianghan Plain.

As shown in Figure 1, Hubei province is an important part of the Yangtze River economic belt. It is the economic hinterland of central China. By the end of 2019, there are 59.27 million permanent residents in Hubei province, including 36.1547 million in urban areas and 23.1153 million in rural areas. The urbanization rate reached $61 \%$. In 2019 , Hubei province's GDP will reach 4582.831 billion yuan, an increase of $7.5 \%$. Hubei is one of the national old industrial bases, and equipment manufacturing industry is an important 
pillar industry in Hubei. In recent years, with the development of industrialization and urbanization, land use has changed greatly, showing the decrease of cultivated land area and the continuous expansion of urban land.

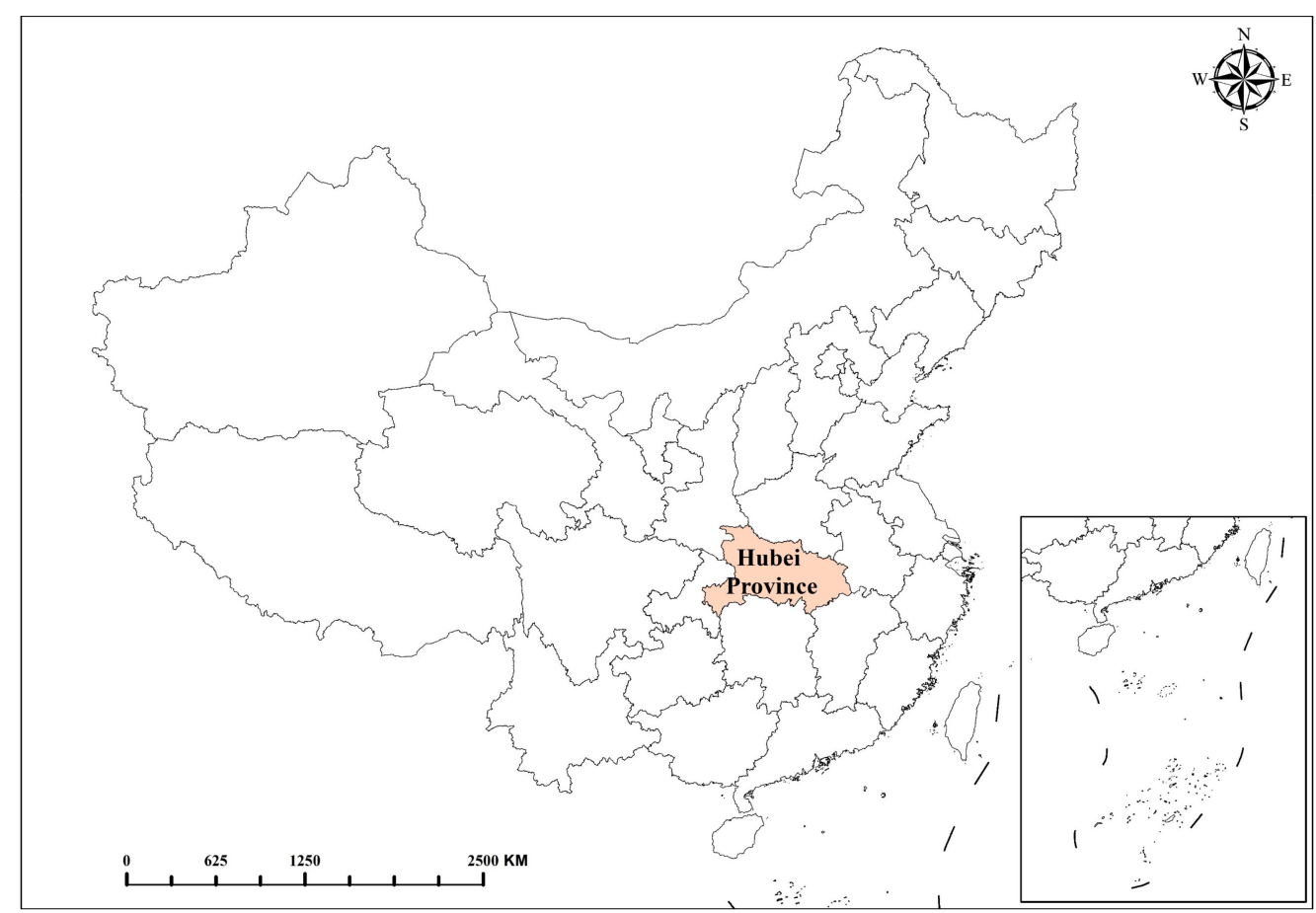

Figure 1. Location of Hubei province.

Taking Hubei province as an example, according to the objective law of regional differences, combined with its development strategy and land use policy, this paper studies the zoning, clarifies the key points of land consolidation, provides reference for relevant departments to arrange land consolidation projects, and provides basis for the compilation of land consolidation planning in Hubei province, which has important practical significance.

\subsection{Data Analysis Methods}

\subsubsection{Self-Organizing Feature Map}

SOMs were first developed by Teuvo Kohonen in 1981. Incorporating a kind of self-learning without mentors, SOMs are self-organizing and self-learning networks that comprise input and output layers [30]. SOM has a strong statistical ability and associative function, which can solve the problem of unsupervised classification. SOM has the characteristics of self-adaptability, self-organization, fault tolerance, and realization of a large number of nonlinear data system analysis for acquiring knowledge of external things. Unlike traditional methods, it has no requirement of normality or linearity for data [31]. SOMs network is divided into input layer and output layer, and it is generally considered that the best arrangement mode is a hexagonal grid. The input layer mainly converges the sample data to the output neuron through weight vector, while the output layer mainly forms relatively stable aggregation state through competition among output neuron, which has different arrangement structure [32,33]. A two-dimensional form (Figure 2) is commonly output. At present, SOM was widely used in the land research field, because it can better identify the complex and nonlinear relationship between the components of cultivated land productivity. From the early reports, it could be found that SOMs were applied to land management [34], soil classification [35-38], and cultivated land productivity zoning [39,40]. 


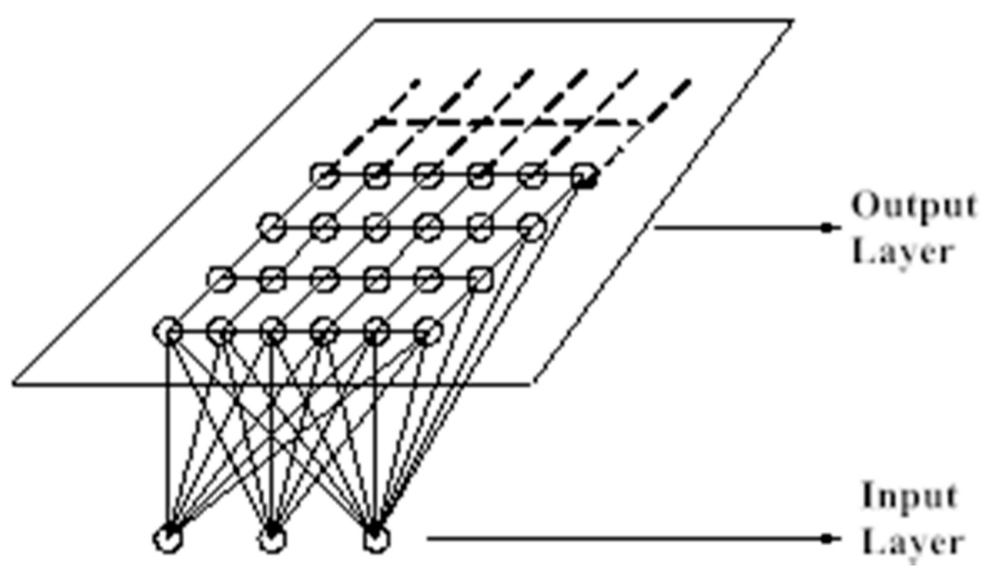

Figure 2. Two-dimensional planar array output from a self-organizing feature map (SOM).

\subsubsection{Hierarchical Clustering}

Hierarchical clustering is an important branch of multivariate statistics. The basic idea of the mathematic method is as follows: each sample first forms its own class, i.e., $\mathrm{N}$ samples give $\mathrm{N}$ classes, and then the (Euclidean) distance between each sample is compared with some distance criterion. The samples with the minimum distance are merged into a new class, resulting in $(\mathrm{N}-1)$ categories, and then the distance between the new category, and the other categories is calculated. The merger process is repeated until the required number of categories is obtained or the distance criterion can no longer be satisfied. Hierarchical clustering is widely used in land use and zoning [41-45], ecological functional zoning [46], and cultivated land protection and compensation [47].

\subsection{Zoning Units and Indicator System}

Seventy-nine zoning units were formed according to the administrative divisions of Hubei province. Based on the data, three districts of Ezhou city were combined as a single unit, named Ezhou City. Based on the indicator system construction theory of land zoning [31] and the availability of data, four indicator categories were selected: natural ecological condition, socioeconomic condition, land-use condition, and land consolidation potential (Table 1). Finally, 18 indicators were chosen; these are also described in Table 1.

Table 1. Indicator system of land consolidation zoning.

\begin{tabular}{|c|c|c|}
\hline Category of Indicator & Meta Indicator & Explanation or Calculation of Indicator \\
\hline $\begin{array}{l}\text { Natural ecological } \\
\text { condition }\end{array}$ & $\begin{array}{l}\text { Geographic and } \\
\text { geomorphic conditions } \\
\text { Forest coverage }(\%)\end{array}$ & $\begin{array}{l}\text { According to the topography of Hubei province, this is divided into four types: } \\
\text { plain, downland, hilly, and mountainous plateau. } \\
\text { Percentage of forested area in a country or region whose canopy density is above } 0.2 \text {. } \\
\text { Degree of ecological fragility and the priority of ecological protection, which can be } \\
\text { divided into national key ecological function areas, national agricultural producing } \\
\text { areas, key ecological function areas of Hubei province, and other key ecological } \\
\text { function areas of Hubei province, provincial key development areas, and national } \\
\text { key development areas. }{ }^{*} \\
\text { Degree of vulnerability to geological disasters, including geological disasters that } \\
\text { may easily occur, geological hazards that may occur, geological disasters that are less } \\
\text { likely to occur, and geological disasters that are generally unlikely to occur. }{ }^{* *}\end{array}$ \\
\hline $\begin{array}{l}\text { Socioeconomic } \\
\text { condition }\end{array}$ & $\begin{array}{l}\text { GDP per capita (CNY) } \\
\text { Disposable income of rural } \\
\text { residents per capita (CNY) } \\
\text { Agricultural machinery total } \\
\text { power per acre }(\mathrm{kw} / \mathrm{ha}) \\
\text { Urbanization rate }(\%) \\
\text { Effective irrigation rate }(\%)\end{array}$ & $\begin{array}{l}\text { Gross domestic product per capita. } \\
\text { Income received by each rural household after initial distribution and redistribution. } \\
\text { Agricultural machinery total power per acre }(\mathrm{kw} / \mathrm{ha})=\text { Total power of agricultural } \\
\text { machinery }(\mathrm{kw}) \text { divided by the area planted with crops (ha). } \\
\text { Urbanization rate }(\%)=\text { urban population divided by the total population. } \\
\text { Effective irrigation rate }(\%)=\text { effective irrigation area (ha) divided by the total } \\
\text { cultivated area }(\text { ha). } \\
\text { Yes or no based on the poverty-stricken counties in the 13th five-year plan period of } \\
\text { Hubei province. }\end{array}$ \\
\hline
\end{tabular}


Table 1. Cont.

\begin{tabular}{|c|c|c|}
\hline Category of Indicator & Meta Indicator & Explanation or Calculation of Indicator \\
\hline \multirow{4}{*}{ Land-use condition } & Land reclamation rate $(\%)$ & $\begin{array}{l}\text { Land reclamation rate }(\%)=\text { total area of cultivated land (ha) divided by the total } \\
\text { area of land (ha). }\end{array}$ \\
\hline & Land use rate $(\%)$ & Land use rate $(\%)=$ used land area (ha) divided by the total land area (ha). \\
\hline & & \\
\hline & $\begin{array}{l}\text { Cultivated area } \\
\text { per capita (ha/person) }\end{array}$ & $\begin{array}{l}\text { Cultivated area per capita (ha/person) }=\text { total area of cultivated land (ha) divided by } \\
\text { the total population. }\end{array}$ \\
\hline \multirow{4}{*}{$\begin{array}{l}\text { Land consolidation } \\
\text { potential }\end{array}$} & $\begin{array}{l}\text { Agricultural land } \\
\text { potential grade }\end{array}$ & $\begin{array}{l}\text { This indicator can reflect the area and quality of cultivated land that can be } \\
\text { renovated in the region. }\end{array}$ \\
\hline & $\begin{array}{l}\text { Rural construction } \\
\text { potential grade }\end{array}$ & $\begin{array}{l}\text { It refers to the grade of the area of effective cultivated land and other land that can } \\
\text { be increased through the transformation of existing rural residential areas and the } \\
\text { relocation and consolidation of villages. The larger the area is, the higher the grade } \\
\text { is. **** }\end{array}$ \\
\hline & $\begin{array}{l}\text { Development } \\
\text { potential grade of unused land }\end{array}$ & $\begin{array}{l}\text { It refers to the area of unused land suitable for cultivated land and other agricultural } \\
\text { land under certain technical and ecological environment conditions. The larger the } \\
\text { area, the higher the grade. }{ }^{* * * * *}\end{array}$ \\
\hline & $\begin{array}{l}\text { Reclamation potential } \\
\text { grade of abandoned land }\end{array}$ & $\begin{array}{l}\text { It refers to the area of arable land and other agricultural land that can be increased } \\
\text { after the remediation measures are taken for the damaged and abandoned land in } \\
\text { the process of production and construction. The larger the area, the higher the } \\
\text { grade. }{ }^{* * * *}\end{array}$ \\
\hline
\end{tabular}

* Based on the plan for ecological construction of Hubei province (2014-2030) and the Hubei province development planning (2012-2020).

** Based on the plan for Hubei province geological hazard prevention and control (2003-2015) and the natural disaster risk analysis and regionalization in China. ${ }^{* * *}$ Based on the Hubei poverty alleviation plan $(2016-2020) .{ }^{* * *}$ Based on the Hubei Province Land Consolidation Plan (2015-2020).

\section{Results}

\subsection{Land Consolidation Zoning Based on SOM}

\subsubsection{Establishment of SOM Classification Network Model}

In this paper, 18 indicators, such as geographic and geomorphic conditions, GDP per capita, land reclamation rate, agricultural land reclamation potential grade, etc., were selected for land consolidation zoning using the SOM method. Data were standardized before analysis. A clustering procedure based on SOM was applied in MATLAB (version R2016a) with functions relating to SOM network initialization, training, and activation. Standardized data of 18 indicators for the 79 units described above were input in MATLAB. Hence, there were 18 neurons with 79 samples in the input layer. A SOM network was then constructed using the "Newsom" function. The output layer was determined to have 12 neurons by considering the actual conditions of Hubei province and related research. Accordingly, the competition layer was set to a $(3 \times 4)$-dimensional network structure. Finally, the initial learning efficiency was set to 0.5 and the other parameters took their default values. The network training steps were set as 10, 510, 1010, 2010, 3010, 4010, 5010, 6010, and 7010, and the clustering result of each step was recorded. The clustering processes based on the SOM network model are described in Figure 3.

\subsubsection{Clustering Results Based on SOM}

The clustering results at different network training steps are shown in Figure 4. The number of samples in each category tends to remain constant once the network training step has reached 5010. Therefore, the clustering result at network training step 5010 was used in the land consolidation zoning scheme. Table 2 presents the detailed clustering results, with land classified into 11 categories. Figure 5 shows the spatial distribution of SOM partition results. 


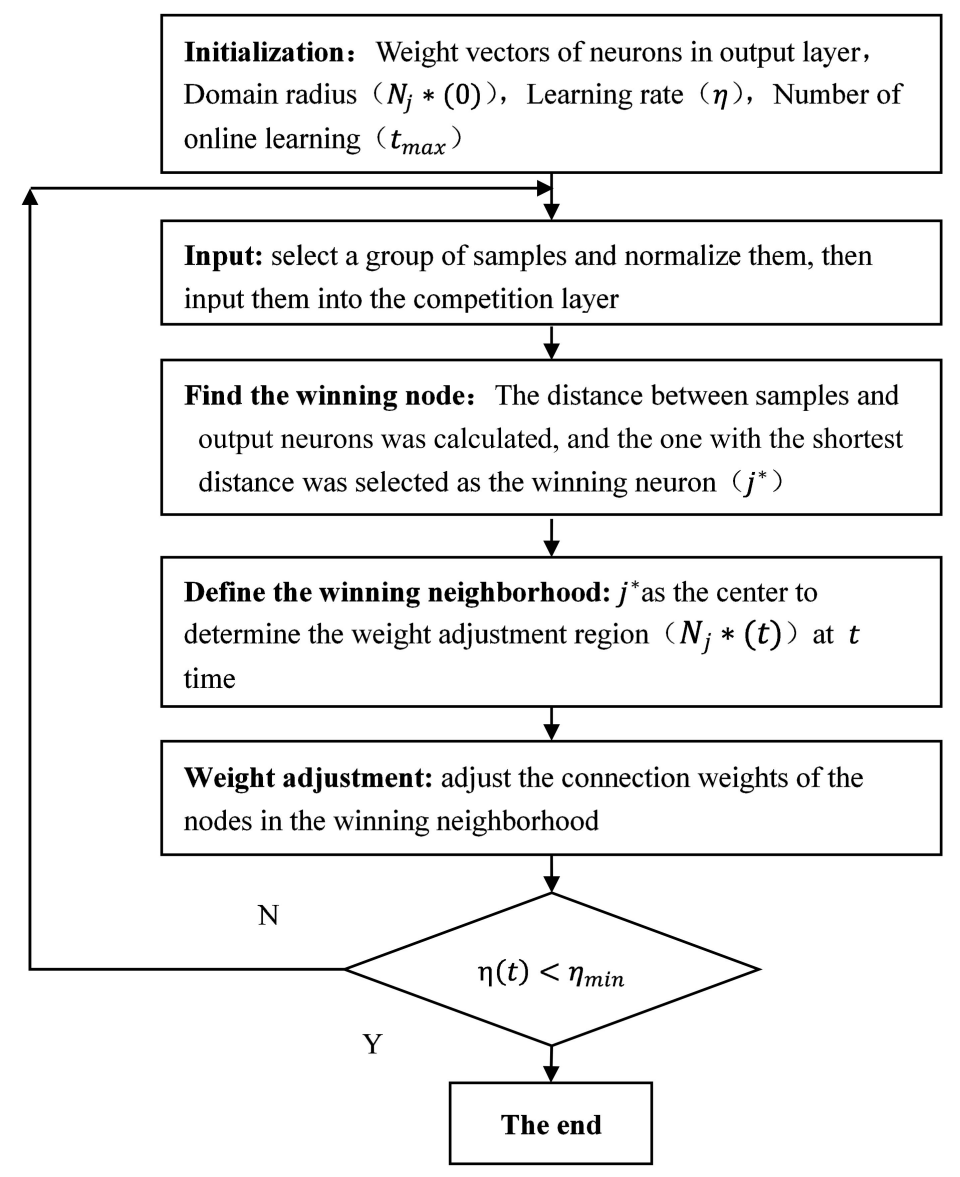

Figure 3. Clustering processes based on SOM network model.

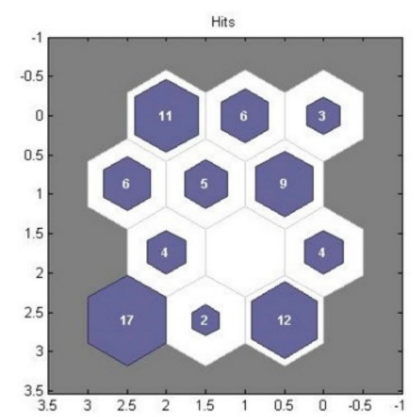

10-Training step

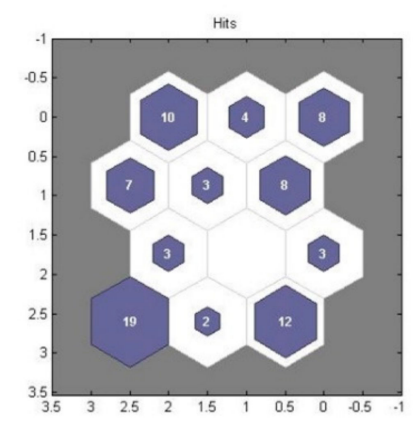

4010-Training step

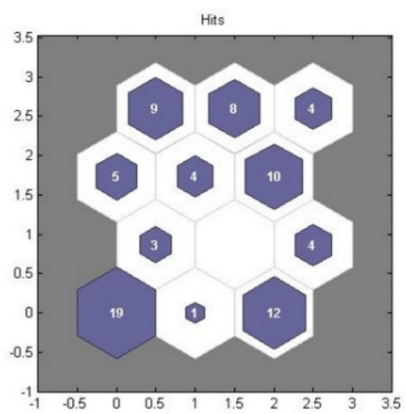

1010-Training step

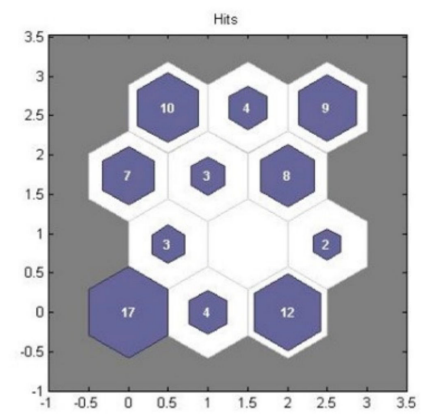

5010-Training step

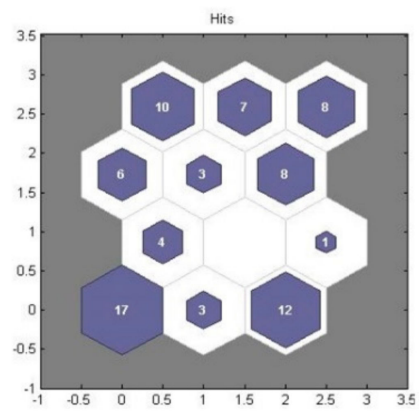

2010-Training step

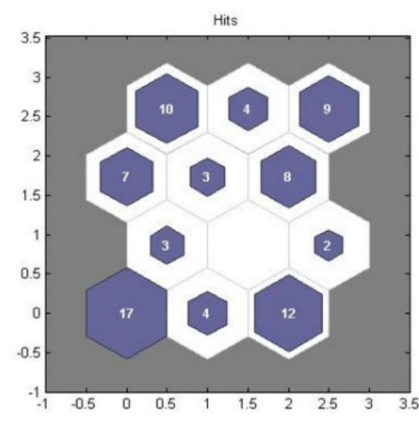

6010-Training step

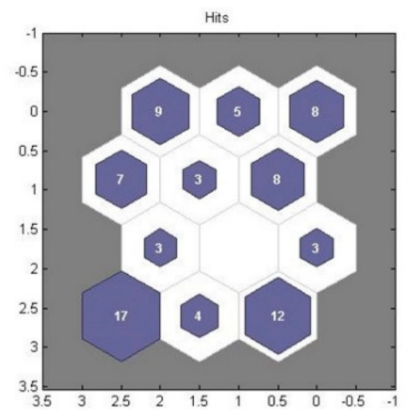

3010-Training step

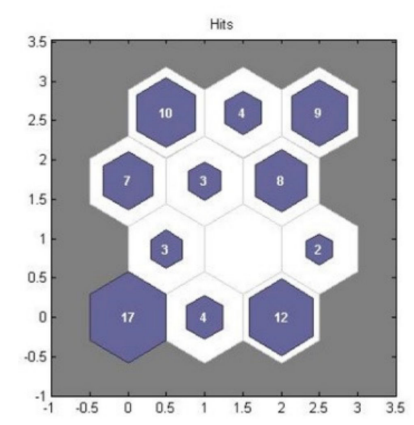

7010-Training step

Figure 4. Results of clustering based on SOM. 
Table 2. Land consolidation zoning classification in Hubei province based on SOM.

\begin{tabular}{cl}
\hline Categories & \multicolumn{1}{c}{ Including Units } \\
\hline I & Xiangzhou District, Zhaoyang City, Yicheng City, Jingshan County, Shayang County, Zhongxiang City, Gongan \\
II & County, Jianli County, Sui County \\
HII & Caidian District, Jiangxia District, Huangpi District, Xinzhou District, Hannan District, Zhijiang City, Xiaonan District, \\
& Yingcheng City, Jingzhou District, Huangzhou District \\
IV & Dangyang City, Laohekou City, Anlu City, Jiangling County, Shishou City, Honghu City, Songzi City, \\
V & Huangmei County \\
VI & Danmeng County, Wuxue City, Jiayu County \\
VII & Xishui County, Guangshui City \\
VIII & Yiling District, Yuanan County, Gucheng County \\
IX & Yangxin County, Xiaochang County, Dawu County, Tuanfeng County, Hongan County, Luotian County, Yingshan \\
X & County, Qichun County, Macheng City, Tongcheng County, Chongyang County, Tongshan County \\
& Yunyang District, Yunxi County, Danjiangkou City, Nanzhang County \\
XI & Zhushan County, Zhuxi County, Fang County, Xingshan County, Zigui County, Changyang County, Wufeng County, \\
& Baokang County, Enshi City, Lichuan City, Jianshi County, Badong County, Xuanen County, Xianfeng County, Laifeng \\
\hline
\end{tabular}

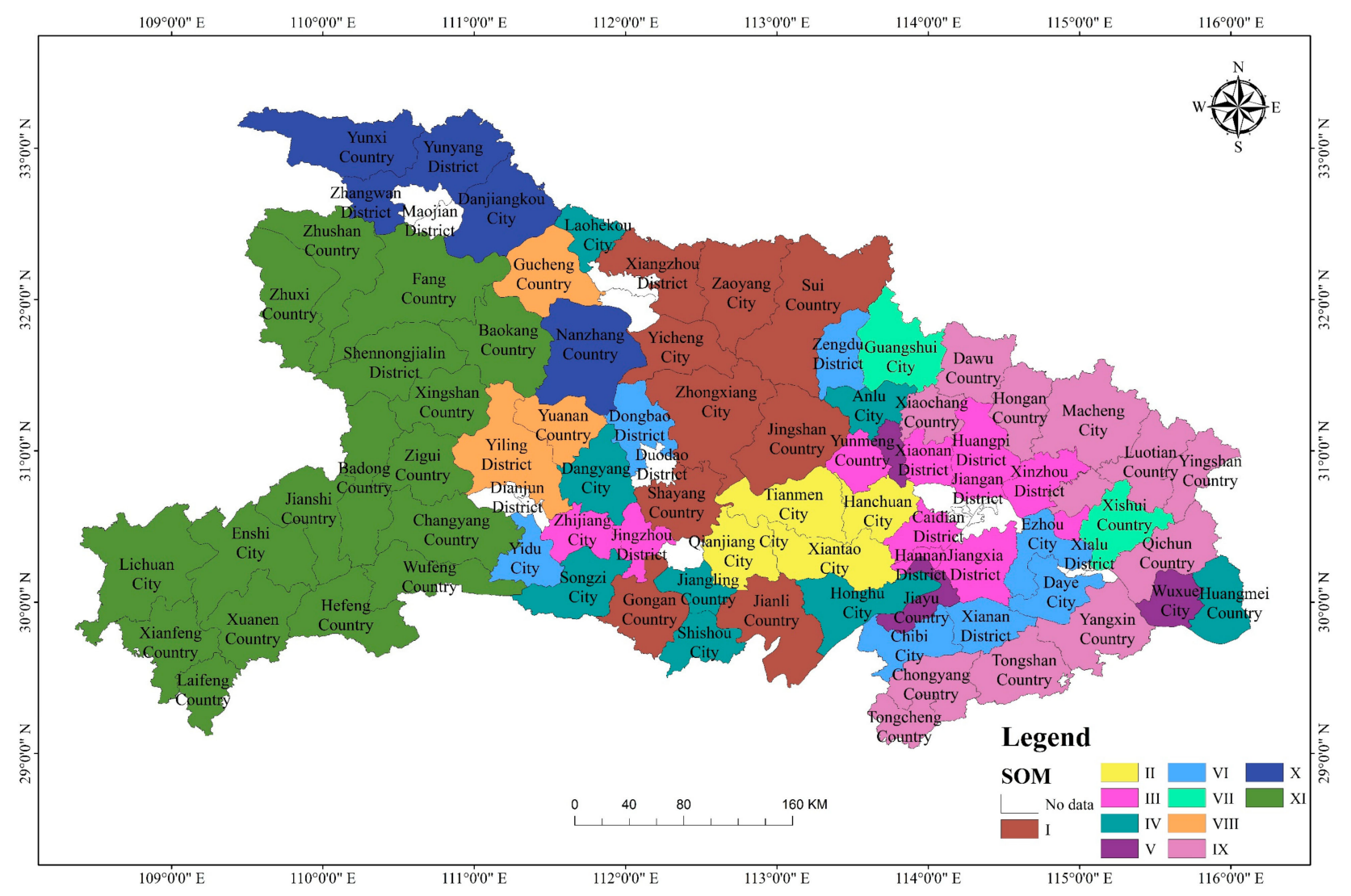

Figure 5. Map of land consolidation zoning scheme in Hubei province (SOM).

\subsection{Land Consolidation Zoning Based on Hierarchical Clustering}

Hierarchical clustering was performed using SPSS (version 19.0) for land consolidation zoning in Hubei province. The processes are described in Figure 6, and the results are presented in Table 3. Hierarchical clustering produced a total of 12 categories. Figure 7 shows the spatial distribution of Hierarchical clustering partition results. 


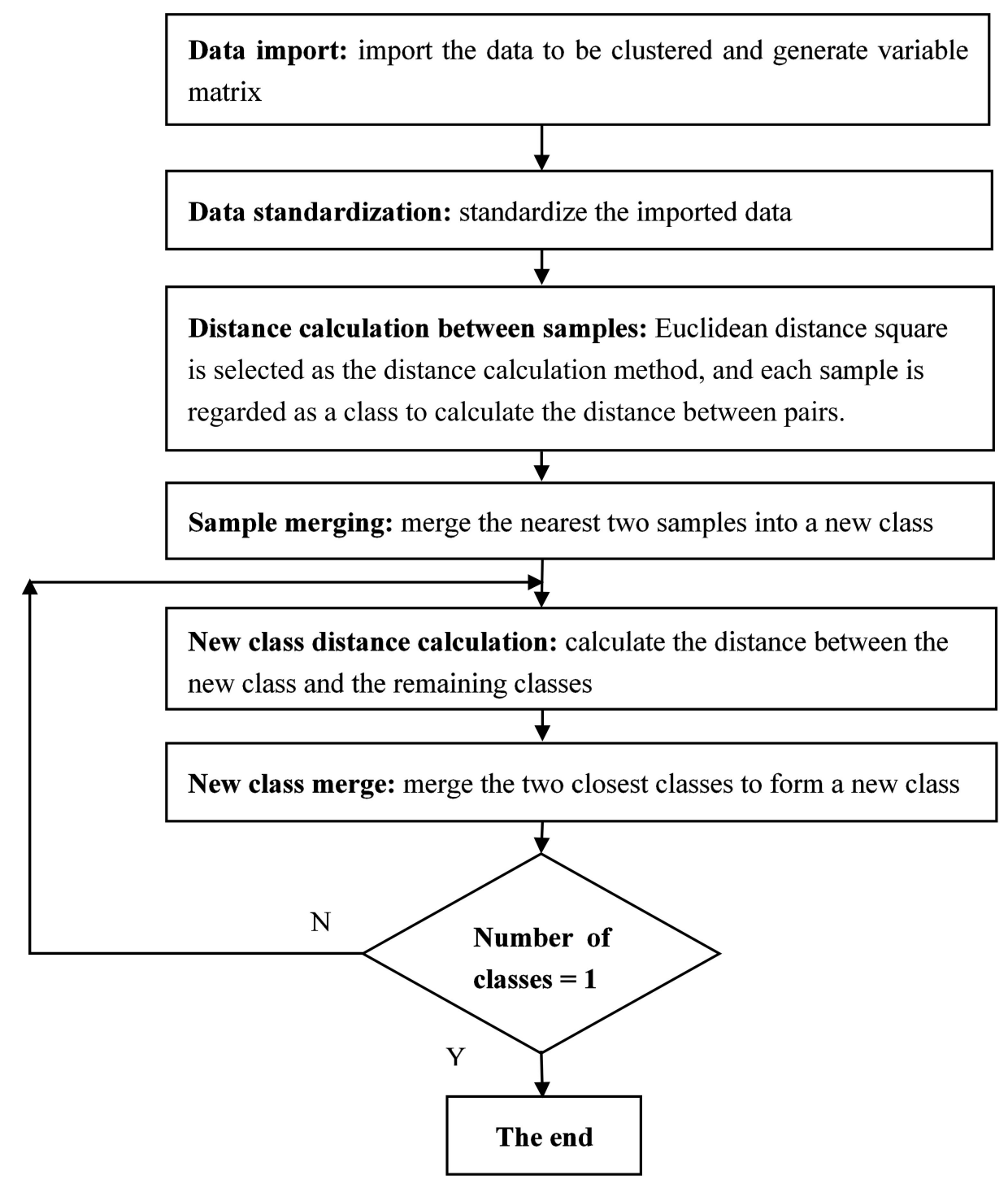

Figure 6. Processes of the Hierarchical clustering method.

Table 3. Land consolidation zoning classification in Hubei province based on Hierarchical clustering method.

\begin{tabular}{cl}
\hline Categories & \multicolumn{1}{c}{ Including Units } \\
\hline I & Dangyang City, Laohekou City, Shayang County, Yunmeng County, Anlu City, Jiangling County, Gongan County, Jianli \\
II & County, Shishou City, Honghu City, Songzi City, Xishui County, Huangmei County, Wuxue City, Jiayu County \\
III & Dongang City, Yicheng City, Jingshan County, Zhongxiang City, Sui County, Guangshui City \\
IV & Caidian District, Jiangxia District, Huangpi District, Xinzhou District, Hannan District, Zhijiang City, Ezhou City, \\
V & Xiaonan District, Yingcheng City, Hanchuan City, Jingzhou District, Xiantao City, Qianjiang City, Tianmen City \\
VI & Yiangzhou District \\
VII & Daye City \\
VIII & Huangzhou District \\
IX & Yuanan County, Nanzhang County, Gucheng County \\
X & Xiaochang County, Dawu County, Tuanfeng County, Hongan County, Luotian County, Yingshan County, Qichun \\
& County, Macheng City, Tongcheng County, Chongyang County, Tongshan County \\
XI & Yunyang District, Yunxi County, Zhushan County, Zhuxi County, Fang County, Danjiangkou City, Xingshan County, \\
& Zigui County, Changyang County, Wufeng County, Baokang County, Enshi City, Lichuan City, Jianshi County, Badong \\
XII & County, Xuanen County, Xianfeng County, Laifeng County, Hefeng County, Shennongjia Forestry District \\
\hline
\end{tabular}




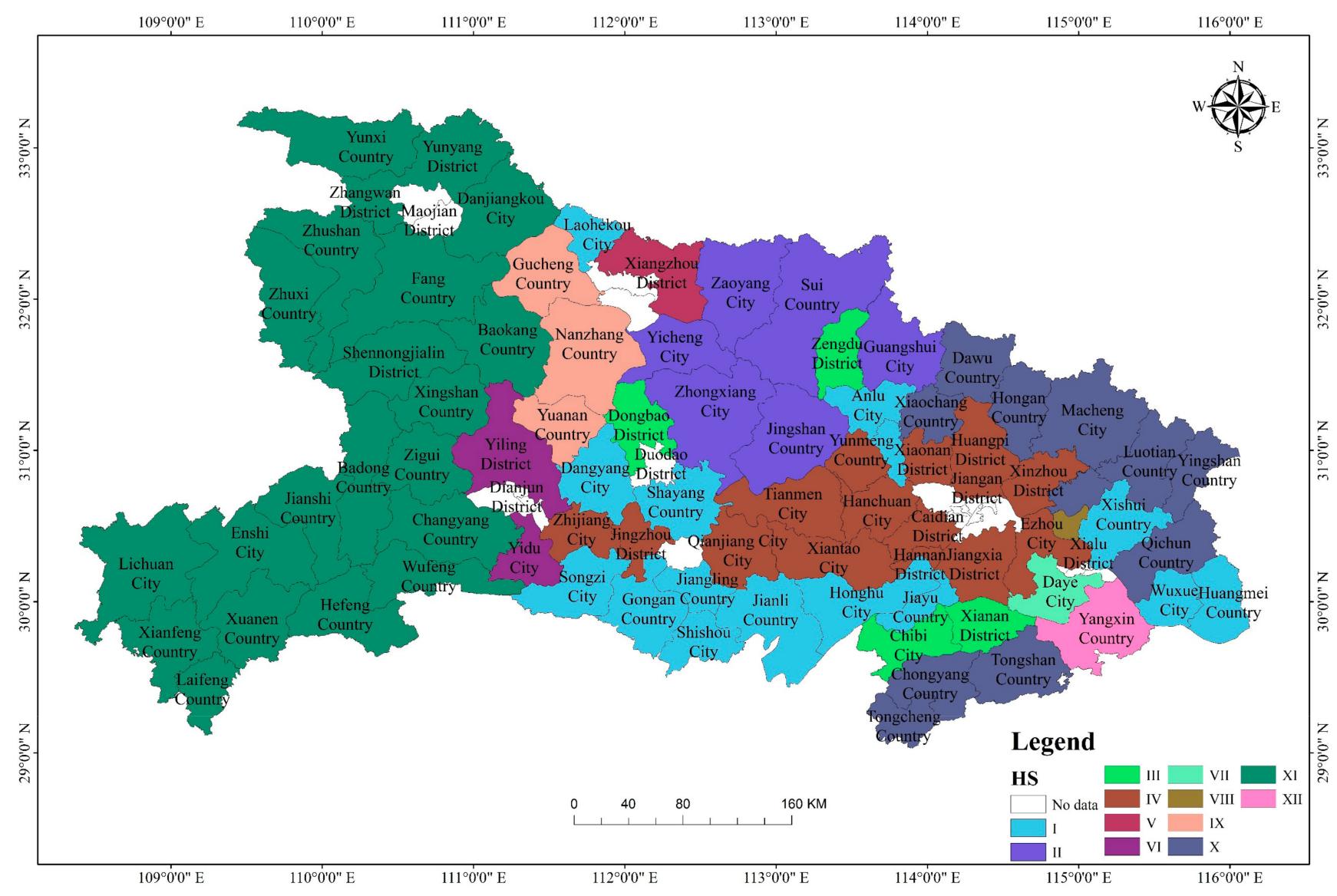

Figure 7. Map of land consolidation zoning scheme in Hubei province (HS).

\subsection{Coupling Analysis of the Two Clustering Results}

The common units from categories II and III of the SOM clustering method and category IV of the hierarchical clustering method were placed in integrated category I. This category includes 13 units, such as Caidian District, Jiangxia District, and Huangpi District (Table 4). These units have high levels of economic development and urban infrastructure construction. However, some of the cultivated land in these units is occupied and there is some inefficient and idle land. Based on the high levels of development in the economy, urbanization, and rural water facilities, Huangzhou District in category III of the SOM clustering and Ezhou City in category IV of the hierarchical clustering can be classified into this integrated category I partition. The key points of land consolidation for this partition can be summarized as follows: strengthen the construction supporting farmland drainage and irrigation infrastructure, and focus on solving the problems of flooding and waterlogging in plain areas; regulate rural residential areas to relieve the pressure on urban land use.

The common units from category I of the SOM clustering and category II of the hierarchical clustering were placed in integrated category II. This includes five units, such as Zaoyang City, Yicheng City, and Jingshan County (Table 4). The units in this partition have a medium level of economic development in Hubei province. The overall grain production capacity is at a high level throughout the province, and there is significant potential for agricultural land consolidation. According to the topography and grain production capacity, Xiangzhou District from category I based on SOM clustering can be classified into this partition. However, Guangshui City in category II of the hierarchical clustering cannot be classified into this partition because it does not have suitable features. The key points of consolidation for this partition lie in agricultural land. Great efforts should be given to the construction of basic farmland with high and constant yields, the 
improvement of rural production conditions, the increase of farmland production at lower cost, and finally the improvement of production enthusiasm among farmers.

Table 4. Integrated category partitions based on comparison of two clustering methods.

\begin{tabular}{|c|c|c|c|}
\hline \multirow[b]{2}{*}{$\begin{array}{l}\text { Integrated Category } \\
\text { Partitions }\end{array}$} & \multirow[b]{2}{*}{$\begin{array}{l}\text { Including Units in Integrated } \\
\text { Category Partitions }\end{array}$} & \multicolumn{2}{|c|}{ Difference between Two Clustering Method } \\
\hline & & $\begin{array}{l}\text { Including Units } \\
\text { (Old Category Based on } \\
\text { SOM Cluster Method) }\end{array}$ & $\begin{array}{c}\text { Including Units } \\
\text { (Old Category Based on } \\
\text { Hierarchical Cluster Method) }\end{array}$ \\
\hline I & $\begin{array}{l}\text { Caidian District, Jiangxia District, } \\
\text { Huangpi District, Xinzhou District, } \\
\text { Hannan District, Zhijiang City, Xiaonan } \\
\text { District, Yingcheng City, Hanchuan } \\
\text { City, Jingzhou District, Xiantao City, } \\
\text { Qianjiang City, Tianmen City }\end{array}$ & $\begin{array}{l}\text { Huangzhou District } \\
\text { (III) }\end{array}$ & $\begin{array}{l}\text { Ezhou City } \\
\text { (IV) }\end{array}$ \\
\hline II & $\begin{array}{l}\text { Zaoyang City, Yicheng City, Jingshan } \\
\text { County, Zhongxiang City, Sui County } \\
\text { Dangyang City, Laohekou City, Anlu }\end{array}$ & $\begin{array}{l}\text { Xiangzhou District } \\
\text { (I) }\end{array}$ & $\begin{array}{l}\text { Guangshui City } \\
\text { (II) }\end{array}$ \\
\hline III & $\begin{array}{l}\text { City, Jiangling County, Shishou City, } \\
\text { Honghu City, Songzi City, Huangmei } \\
\text { County, Yunmeng County, Wuxue City, } \\
\text { Jiayu County }\end{array}$ & $(\mathrm{IV} / \mathrm{V})$ & $\begin{array}{l}\text { Gongan County, Jianli County, } \\
\text { Shayang County, Xishui County } \\
\text { (I) }\end{array}$ \\
\hline IV & $\begin{array}{l}\text { Dongbao District, Xianan District, } \\
\text { Chibi City, Zengdu District }\end{array}$ & $\begin{array}{l}\text { Dazhi City, Yidu City } \\
\text { (VI) }\end{array}$ & (III) \\
\hline $\mathrm{V}$ & $\begin{array}{l}\text { Xiaochang County, Dawu County, } \\
\text { Tuanfeng County, Hongan County, } \\
\text { Luotian County, Yingshan County, } \\
\text { Qichun County, Macheng City, } \\
\text { Tongcheng County, Chongyang County, } \\
\text { Tongshan County }\end{array}$ & $\begin{array}{l}\text { Yangxin County } \\
\text { (IX) }\end{array}$ & $(\bar{X})$ \\
\hline VI & $\begin{array}{l}\text { Yiling District, Yuanan County, } \\
\text { Gucheng County }\end{array}$ & (VIII) & $\begin{array}{l}\text { Nanzhang County, Yidu City } \\
\text { (VI/IX) }\end{array}$ \\
\hline Unclassified & $\begin{array}{l}\text { Zhushan County, Zhuxi County, Fang } \\
\text { County, Xingshan County, Zigui } \\
\text { County, Changyang County, Wufeng } \\
\text { County, Baokang County, Enshi City, } \\
\text { Lichuan City, Jianshi County, Badong } \\
\text { County, Xuanen County, Xianfeng } \\
\text { County, Laifeng County, Hefeng } \\
\text { County, Shennongjia Forestry District } \\
\text { Guangshui City, Xishui County }\end{array}$ & $(\overline{X I})$ & $\begin{array}{c}\text { Yunyang District, Yunxi District, } \\
\text { Danjiangkou City } \\
\text { (XI) }\end{array}$ \\
\hline Unclassified & Guangshui City, Xishui County & & \\
\hline
\end{tabular}

The common units from categories IV and V of the SOM clustering and category I of the hierarchical clustering were combined to form integrated category III. This includes 11 units, such as Dangyang City, Laohekou City, and Anlu City (Table 4). The soil in these areas is good for grain production. Therefore, units in this partition have great food production capacity. In other words, they are the main areas of agricultural production. The land in this partition offers medium potential for consolidation. On account of these characteristics, Gongan County, Jianli County, and Shayang County were selected from category I of the hierarchical clustering method. However, Xishui County cannot be classified into this partition, because the topography of this unit is mostly low hills instead of river plains. The key points of land consolidation in this area lie in the comprehensive improvement of agriculture. Systematic plans should aim to adapt to local conditions and highlight regional features, and finally promote comprehensive consolidation of farmland, water, roads, forests, and villages. Efforts should be made to protect cultivated land, enhance the production and supply capacity of agricultural products, and lay the foundations for building a large-scale modern ecological agriculture industry. 
Common units from category VI of the SOM clustering and category III of the hierarchical clustering were placed in integrated category IV. This includes Dongbao District, Xianan District, Chibi City, and Zengdu District (Table 4). These units all belong to key development areas, and are all municipal districts of prefecture-level cities, except for Chibi City. These units are undergoing a period of rapid development in terms of urbanization, and their potential for regional rural construction land consolidation is high. According to these characteristics, Dazhi City, which was in category VI of the SOM clustering, can be classified into this partition. However, as the terrain of Yidu City is mostly hilly and mountainous, and the city is the main agricultural production area, Yidu City cannot be classified into this new partition. The key points of land consolidation in this area should lie in improving rural construction land, strictly controlling the size of cities and towns, and optimizing the distribution of urban land. At the same time, we should improve and reuse existing land to meet the needs of urbanization and ensure its sustainable development.

The common units from category IX of the SOM clustering and category $X$ of the hierarchical clustering made up integrated category V. This includes 11 units, such as Xiaochang County, Dawu County, and Tuanfeng County (Table 4). The units in this partition have relatively low levels of economic development and overall grain production capacity. Some areas are vulnerable to geological disasters. According to these characteristics, Yangxin County, which was in category IX of the SOM clustering, can be classified into this new partition. Yangxin County is a key poverty-stricken county located in the hilly area of southeast Hubei province, which is prone to geological disasters. Land consolidation in this region should focus on the targeted poverty alleviation policy. On the premise of protecting the ecological environment, the improvement of agricultural land should be vigorously promoted in contiguous poverty-stricken areas, with increased funding for poverty alleviation and a gradual improvement in farmers' production and living conditions.

The common units from category VIII of the SOM clustering and categories VI and IX of the hierarchical clustering made up integrated category VI. The three units in this partition are Yiling District, Yuanan County, and Gucheng County (Table 4). This new partition has a high grain production capacity. Gucheng County is a major agricultural production area. At present, the unit is focusing on building the "China organic valley," with high-end grain and oil industries, organic vegetable demonstration areas, and ecological leisure tourism. Yuancheng County and Yidu City belong to the main production area of Yi-Jing agricultural products, and are accelerating the development of superior characteristic industries, such as aquaculture, animal husbandry, and forest products. Overall, the areas in this new partition have high levels of economic development, and are located in hills and mountains that are prone to geological disasters. According to these characteristics, Nanzhang County and Yidu City, which were in categories VI and IX of the hierarchical clustering, can be classified into this new partition. The key points to the consolidation of this region lie in improving basic facilities in major grain-producing areas and basic farmland protection areas, and the appropriate division of rural construction land for the construction of industrial and eco-leisure areas.

The common units from category XI of the SOM clustering and category XI of the hierarchical clustering formed integrated category VII. This partition has 17 units, such as Zhushan County, Zhuxi County, and Fang County (Table 4). Most of the units in this new partition are located in key national ecological functional areas and belong to key ecological protection areas. The overall level of regional economic development in these areas is relatively low. All regions are key targets of poverty alleviation during the 13th five-year plan period. Grain production capacity is low, and farmers' incomes are correspondingly low. According to these characteristics, Yunyang District, Yunxi County, and Danjiangkou City, which were in category XI of the hierarchical clustering, can be classified into this new partition. The key points of land consolidation in these areas lie in two factors. First, we should vigorously promote the improvement of agricultural land in contiguous povertystricken areas, and promote the protection of cultivated land in terms of quantity, quality, and ecology. Second, we should actively develop good ecological farmland construction 
and ecological land improvement, and develop featured agriculture, forests, and animal husbandry in areas with serious land degradation and fragile ecological environments.

Finally, Guangshui City and Xishui County were left unclassified (Table 4). As the main agricultural production area of our County, Guangshui City has a high grain production capacity, which is consistent with the characteristics of integrated category III. In other words, Guangshui City can be classified into this new partition. Xishui County is mainly characterized by low hills and relatively low levels of economic development, which is consistent with the characteristics of integrated category V. Therefore, Xishui County can be classified into this new partition.

\subsection{Land Consolidation Zoning Scheme for Hubei Province}

After analyzing the two clustering results, the land consolidation zoning scheme for Hubei province can be formulated. Seven integrated category partitions were determined for land consolidation (Table 5). The areas in partition I require the coordination of urban and rural development. The areas in partition II are the key management areas for agricultural land, whereas those in partition III should be designated as comprehensive agricultural improvement areas. The areas in partition IV should be optimized for urban development and improvement, and partition $\mathrm{V}$ consists of key areas for poverty alleviation. The areas in partition VI should be designated for modern agricultural regulation. Finally, partition VII contains ecological land improvement areas. A distribution map showing the land consolidation zoning scheme in Hubei province is presented in Figure 8.

Table 5. Land consolidation zoning scheme for Hubei province.

\begin{tabular}{|c|c|}
\hline $\begin{array}{l}\text { Integrated } \\
\text { Categories }\end{array}$ & Including Units \\
\hline I & $\begin{array}{l}\text { Caidian District, Jiangxia District, Huangpi District, Xinzhou District, Hannan District, Zhijiang City, Xiaonan } \\
\text { District, Yingcheng City, Hanchuan City, Jiangzhou District, Huangzhou District, Ezhou City, Xiantao City, } \\
\text { Qianjiang City, Tianmen City }\end{array}$ \\
\hline II & $\begin{array}{l}\text { Zaoyang City, Yicheng City, Jiangshan County, Zhongxiang City, Sui County, Xiangzhou District } \\
\text { Dangyang City, Laohekou City, Anlu City, Jiangling County, Shishou City, Honghu City, Songzi City, Huangmei }\end{array}$ \\
\hline III & $\begin{array}{l}\text { County, Yunmeng County, Wuxue City, Jiayu County, Gongan County, Jianli County, Shayang County, } \\
\text { Guangshui City }\end{array}$ \\
\hline IV & Dongbao District, Xianan District, Chibi City, Zengdu District, Dazhi City \\
\hline V & $\begin{array}{l}\text { Xiaochang County, Dawu County, Tuanfeng County, Hongan County, Luotian County, Yingshan County, Qichun } \\
\text { County, Macheng City, Tongcheng County, Chongyang County, Tongshan County, Yangxin County, Xishui County }\end{array}$ \\
\hline VI & $\begin{array}{l}\text { Yiling District, Yuanan District, Gucheng County, Nanzhang County, Yidu City } \\
\text { Zhushan County, Zhuxi County, Fang County, Xingshan County, Zigui County, Changyang County, Wufeng County, }\end{array}$ \\
\hline VII & $\begin{array}{l}\text { Baokang County, Enshi City, Lichuan City, Jianshi County, Badong County, Xuanen County, Xianfeng County, } \\
\text { Laifeng County, Hefeng County, Shennongjia Forestry District, Yunyang District, Yunxi County, Danjiangkou City }\end{array}$ \\
\hline
\end{tabular}




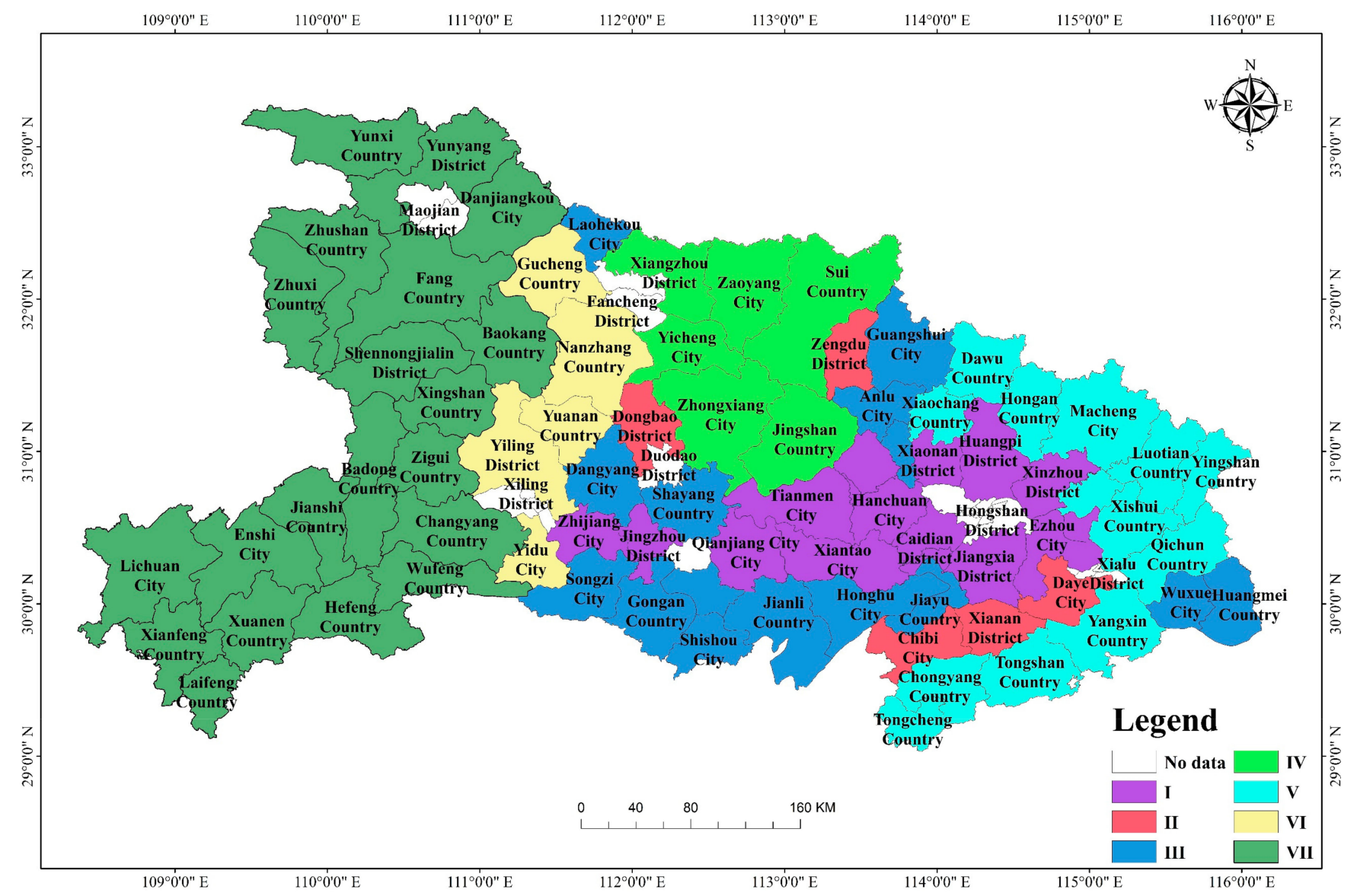

Figure 8. Map of land consolidation zoning scheme in Hubei province.

\section{Discussions}

Land consolidation started earlier in other countries outside China. During the practice, scientific cognition, idea, and method were formed [16]. The land has multiple attributes, such as nature properties, social economy, and ecological environment; hence, multiple aspects should be considered when the cultivated land is under zoning consolidation. It is proposed that different regions should take different practice activities to implement differentiated land consolidation programs based on the level of economic and social development and the characteristics of natural resources. Many scholars have gradually started to furtherly develop the relevant theoretical and empirical studies.

By studying the farmland consolidation in Japan, Mihara [48] pointed out that it had a good compaction effect on the surface layer of paddy fields and the soil on the slope to reduce the soil permeability; thus, reducing the probability of erosion in paddy fields. Sonnenberg [49] believes that land consolidation not only optimizes road systems, but also plays an important role in improving water management systems and natural landscape conditions. Some scholars also pointed out that a series of engineering and biological measures in the implementation of land remediation may impact the quantity and quality of surface vegetation [50]. For example, Thomas [51] pointed out that if the goal of land consolidation is only limited to improving agricultural productivity and production conditions, the implementation of land consolidation is likely to have a negative impact on the ecological environment. Sklenicka [52] selected the properties of the land, natural resource conditions, economic conditions, and other aspects as evaluation indicators to carry out benefit evaluation before and after the implementation of three different land consolidation projects in the Czech Republic. The results show that the determination of initial evaluation criteria and evaluation model has a significant impact on the benefits of land remediation projects. 
In this study, the main factors affecting the land consolidation activities were analyzed based on the related theories of soil consolidation zoning. In combination with the strategic positioning and relevant policies of regional land consolidation, a reasonable regional evaluation index system was established. Finally, the regional land consolidation zoning scheme was obtained through the comparative analysis of two clustering methods. Make clear the key points of land consolidation in each partition. It provides reference for the development of regional land consolidation.

However, the indicators selected for evaluation in this paper still exhibited a degree of subjectivity and had certain limitations. In addition, the influence of some micro-indicators on land consolidation zoning, such as the concentration and contiguity of cultivated lands, was ignored. Therefore, further attempts at enhancing the indicator selection process may result in better land consolidation zoning.

For example, the indicators for the evaluation of regional ecological conditions in this paper are all qualitative indicators, which are subjective and limited to a certain extent. Relevant opinions and suggestions should continue to be widely collected to achieve a more scientific and reasonable judgment of the importance of indicators. Due to the lack of statistical data and feasibility considerations, this paper selected counties (cities, districts) as subdivision units, and may ignore the impact of some micro indicators on the regulation subdivision, such as the degree of farmland concentration and connectivity, which needs to be further explored.

\section{Conclusions}

This paper described a method for realizing land remediation zoning based on an indicator system. The following four conclusions can be made.

(1) Based on the consideration of natural resources, economic development, social indicators, and the ecological environment, and combined with the strategic positioning and policy guidance of land improvement in Hubei province, the proposed evaluation system of land consolidation zoning indicators is both comprehensive and scientific.

(2) SOM clustering was first applied for land consolidation zoning in Hubei province, and 11 categories were determined. SOMs are self-learning, self-adapting systems with a degree of fault-tolerance. Therefore, they improve the rationality, objectivity, and repeatability of the resulting categories, and ensure the objectivity and reliability of the results.

(3) Hierarchical clustering was also applied for land consolidation zoning in Hubei province, determining a total of 12 categories. These results were reasonable, and were in line with the real situation of Hubei province.

(4) Integrating the advantages of SOM neural network clustering with those of hierarchical clustering, seven category partitions for the land consolidation zoning scheme in Hubei province were determined. According to different zoning characteristics, this paper has described the corresponding key points for land consolidation, providing a reference for relevant departments to arrange land consolidation projects, a scientific basis for the preparation of land consolidation planning in Hubei province, and a foundation for further spatial studies.

Author Contributions: Conceptualization, C.Z. and P.X.; methodology, C.Z. and Y.Z.; software, P.X. and H.F.; formal analysis, X.L.; resources, J.J. All authors have read and agreed to the published version of the manuscript.

Funding: This research was funded by National Natural Science Foundation of China (41271534) and Annual evaluation project of cultivated land quality grade of Hubei Provincial Department of land and resources in 2017 (hbzszb-2017-030).

Institutional Review Board Statement: Not applicable.

Informed Consent Statement: Not applicable. 
Data Availability Statement: The data presented in this study are available on request from the corresponding author.

Acknowledgments: The authors wish to thank all other members of our lab for their efforts in the data collection. We thank Stuart Jenkinsonfor editing the English text of a draft of this manuscript.

Conflicts of Interest: The authors declare no conflict of interest.

\section{References}

1. Li, Y.; Wu, W.; Liu, Y. Land consolidation for rural sustainability in China: Practical reflections and policy implications. Land Use Policy 2018, 74, 137-141. [CrossRef]

2. Demetriou, D. The assessment of land valuation in land consolidation schemes: The need for a new land valuation framework. Land Use Policy 2016, 54, 487-498. [CrossRef]

3. Len, P. An algorithm for selecting groups of factors for prioritization of land consolidation in rural areas. Comput. Electron. Agr. 2018, 144, 216-221. [CrossRef]

4. Luo, W.; Timothy, D.J. An assessment of farmers' satisfaction with land consolidation performance in China. Land Use Policy 2017, 61, 501-510. [CrossRef]

5. Wang, J.; He, T.; Lin, Y. Changes in ecological, agricultural, and urban land space in 1984-2012 in China: Land policies and regional social-economical drivers. Habitat Int. 2018, 71, 1-13. [CrossRef]

6. Jiang, G.; Zhang, R.; Ma, W.; Zhou, D.; Wang, X.; He, X. Cultivated land productivity potential improvement in land consolidation schemes in Shenyang, China: Assessment and policy implications. Land Use Policy 2017, 68, 80-88. [CrossRef]

7. Lin, K. Determining Key Ecological Indicators for Urban Land Consolidation. Int. J. Strateg. Prop. Manage. 2010, 14, 89-103. [CrossRef]

8. Podhrázská, J.; Vaishar, A.; Toman, F.; Knotek, J.; Ševelová, M.; Stonawská, K.; Vasylchenko, A.; Karásek, P. Evaluation of Land Consolidation Process by Rural Stakeholders. Eur. Countrys. 2015, 7, 144-155. [CrossRef]

9. Stańczuk-Gałwiaczek, M.; Sobolewska-Mikulska, K.; Ritzema, H.; van Loon-Steensma, J.M. Integration of water management and land consolidation in rural areas to adapt to climate change: Experiences from Poland and the Netherlands. Land Use Policy 2018, 77, 498-511. [CrossRef]

10. Mansberger, R.; Seher, W. Land Administration and Land Consolidation as Part of Austrian Land Management. EU Agrar. Law 2017, 6, 68-76. [CrossRef]

11. Kupidura, A.; Łuczewski, M.; Home, R.; Kupidura, P. Public perceptions of rural landscapes in land consolidation procedures in Poland. Land Use Policy 2014, 39, 313-319. [CrossRef]

12. Janus, J.; Taszakowski, J. Spatial differentiation of indicators presenting selected barriers in the productivity of agricultural areas: A regional approach to setting land consolidation priorities. Ecol. Indic. 2018, 93, 718-729. [CrossRef]

13. Yan, J.; Xia, F.; Bao, H.X.H. Strategic planning framework for land consolidation in China: A top-level design based on SWOT analysis. Habitat Int. 2015, 48, 46-54. [CrossRef]

14. Mwathunga, E.; Donaldson, R. Urban land contestations, challenges and planning strategies in Malawi's main urban centres. Land Use Policy 2018, 77, 1-8. [CrossRef]

15. Long, H. Land consolidation: An indispensable way of spatial restructuring in rural China. J. Geogr. Sci. 2014, 24, 211-225. [CrossRef]

16. Bangbang, Z.; Wenhao, N.; Xuyang, Z.; Xiangbin, K.; Wenju, Y.; Haibin, C. Farmer-dominated pattern land consolidation to solve arable land fragmentation and its effectiveness evaluation in Guangxi. Trans. Chin. Soc. Agric. Eng. 2019, 35, $265-274$.

17. Mazzocchi, C.; Sali, G.; Corsi, S. Land use conversion in metropolitan areas and the permanence of agriculture: Sensitivity Index of Agricultural Land (SIAL), a tool for territorial analysis. Land Use Policy 2013, 35, 155-162. [CrossRef]

18. Cay, T.; Iscan, F. Fuzzy expert system for land reallocation in land consolidation. Expert. Syst. Appl. 2011, 38, 11055-11071. [CrossRef]

19. Xuejiao, L.; Wu, X.; Sucui, L.; Qiyuan, W.; Chunmeng, Z.; Miaomiao, Z. Land reclamation zoning of Chaohu Lake Basin based on GIS and grey constellation clustering. Trans. Chin. Soc. Agric. Eng. 2018, 34, 253-262.

20. Yaslioglu, E.; Akkaya Aslan, S.T.; Kirmikil, M.; Gundogdu, K.S.; Arici, I. Changes in Farm Management and Agricultural Activities and Their Effect on Farmers' Satisfaction from Land Consolidation: The Case of Bursa-Karacabey, Turkey. Eur. Plan. Stud. 2009, 17, 327-340. [CrossRef]

21. Yu, G.; Feng, J.; Che, Y.; Lin, X.; Hu, L.; Yang, S. The identification and assessment of ecological risks for land consolidation based on the anticipation of ecosystem stabilization: A case study in Hubei Province, China. Land Use Policy 2010, 27, 293-303. [CrossRef]

22. Xiao, P.; Zhou, Y.; Li, X.; Xu, J.; Zhao, C. Assessment of Heavy Metals in Agricultural Land: A Literature Review Based on Bibliometric Analysis. Sustainability 2021, 13, 4559. [CrossRef]

23. Zhao, C.; Zhou, Y.; Jiang, J.; Xiao, P.; Wu, H. Spatial characteristics of cultivated land quality accounting for ecological environmental condition: A case study in hilly area of northern Hubei province, China. Sci. Total. Environ. 2021, $774,145765$. [CrossRef] 
24. Yan, J.; Shen, Y.; Xia, F. Differentiated Optimization of Sustainable Land Use in Metropolitan Areas: A Demarcation of Functional Units for Land Consolidation. Sustainability 2017, 9, 1356. [CrossRef]

25. Janus, J.; Ertunç, E. The impact of differences in land fragmentation parameters on the planning, implementation, and evaluation of land consolidation projects. Case studies of Turkey and Poland. Comput. Electron. Agr. 2020, 179, 105813. [CrossRef]

26. Wang, Y.; Li, Y. Promotion of degraded land consolidation to rural poverty alleviation in the agro-pastoral transition zone of northern China. Land Use Policy 2019, 88, 104114. [CrossRef]

27. Sulonen, K.; Kotilainen, S. Lessor's Status in Land Consolidation in Europe-Reports from Cyprus, Finland, France, Germany, the Netherlands, Latvia and Estonia. Balt. J. Real Estate Econ. Constr. Manage. 2015, 3, 56-71. [CrossRef]

28. Zhao, C.; Zhou, Y.; Li, X.; Xiao, P.; Jiang, J. Assessment of Cultivated Land Productivity and Its Spatial Differentiation in Dongting Lake Region: A Case Study of Yuanjiang City, Hunan Province. Sustainability 2018, 10, 3616. [CrossRef]

29. Chartin, C.; Evrard, O.; Salvador-Blanes, S.; Hinschberger, F.; Van Oost, K.; Lefèvre, I.; Daroussin, J.; Macaire, J. Quantifying and modelling the impact of land consolidation and field borders on soil redistribution in agricultural landscapes (1954-2009). Catena 2013, 110, 184-195. [CrossRef]

30. Oy, L.; Vesanto, J.; Himberg, J.; Esa, A.; Parhankangas, J. SOM Toolbox for Matlab 5; Helsinki University of Technology: Espoo, Finland, 2000; p. 2.

31. Teuvo, K. Self-Organizing Maps; Springer: Berlin/Heidelberg, Germany; New York, NY, USA, 2001; pp. 585-622.

32. Liu, Y.; Weisberg, R.H. A Review of Self-Organizing Map Applications in Meteorology and Oceanography; IntechOpen: London, UK, 2011.

33. Tsakovski, S.; Astel, A.; Simeonov, V. Assessment of the water quality of a river catchment by chemometric expertise. J. Chemometr. 2010, 24, 694-702. [CrossRef]

34. Wang, B.; Li, H.; Sun, D. Social-Ecological Patterns of Soil Heavy Metals Based on a Self-Organizing Map (SOM): A Case Study in Beijing, China. Int. J. Environ. Res. Public Health 2014, 11, 3618-3638. [CrossRef] [PubMed]

35. Stankiewicz, A.; Kosiba, P. Advances in ecological modelling of soil properties by self-organizing feature maps of natural environment of Lower Silesia (Poland). Acta Soc. Bot. Pol. 2009, 78, 167. [CrossRef]

36. Merdun, H. Self-organizing map artificial neural network application in multidimensional soil data analysis. Neural Comput. Appl. 2011, 20, 1295-1303. [CrossRef]

37. Petrov, N.; Georgieva, A.; Jordanov, I. Self-organizing maps for texture classification. Neural Comput. Appl. 2013, 22, 1499-1508. [CrossRef]

38. Rivera, D.; Sandoval, M.; Godoy, A. Exploring soil databases: A self-organizing map approach. Soil. Use Manage. 2015, 31, 121-131. [CrossRef]

39. Jiang, Y.; Hou, L.; Shi, T.; Ning, Y. Spatial Zoning Strategy of Urbanization Based on Urban Climate Co-Movement: A Case Study in Shanghai Mainland Area. Sustainability 2018, 10, 2706. [CrossRef]

40. Yajie, H.; Huichun, Y.; Shiwen, Z.; Wenju, Y.; Yuanfang, H. Zoning of Arable Land Productivity Based on Self-organizing Map in China. Sci. Agric. Sin. 2015, 1136-1150.

41. Yajie, Z.; Junling, Z.; Yang, Y.; Shenghua, L.; Li, J. Application of Hierarchical Clustering Analysis Method to Land Use Regionalization in Lianzhou. Sci. Technol. Manage. Land Resour. 2007, 24, 71-76.

42. Tian, L.; Liu, Y.Z.; Yi, Z.X.; Yan, L.; Gui, Z.W.; Hu, L. Comparative Research on the Impact of Correlation between Clustering Factors on Land Use Zoning: A Case Study of Linxiang, China. Appl. Mech. Mater. 2013, 295-298, 2481-2485. [CrossRef]

43. Jiqiang, N.; Jinru, X.; Feng, X.; Zhifeng, C. Design and Implementation of spatial clustering system for land use zoning. Sci. Surv. Mapp. 2013, 38, 178-180.

44. Sidorova, V.S. Hierarchical cluster algorithm for remote sensing data of earth. Pattern Recognit. Image Anal. 2012, 22, 373-379. [CrossRef]

45. Yoon, H. Interrelationships between retail clusters in different hierarchies, land value and property development: A panel VAR approach. Land Use Policy 2018, 78, 245-257. [CrossRef]

46. Wenheng, W.; Zewei, X.; Xinjun, Y. Quantitative research of spatial development differentiation in Xi'an from the perspective of urban functional zoning. Geogr. Res. Aust. 2012, 31, 2173-2184.

47. Wang, K.; Ou, M.; Wolde, Z. Regional Differences in Ecological Compensation for Cultivated Land Protection: An Analysis of Chengdu, Sichuan Province, China. Int. J. Environ. Res. Public Health 2020, 17, 8242. [CrossRef]

48. Mihara, M. Effects of Agricultural Land Consolidation on Erosion Processes in Semi-Mountainous Paddy Fields of Japan. J. Agric. Eng. Res. 1996, 64, 237-247. [CrossRef]

49. Sonnenberg, J. The European dimensions and land management policy issues (land readjustment and land consolidation as tools for development). Land Manage. Process. Transit. 1996, 7, 2-3.

50. Jun, W.; Zheng, L.; Zhongke, B.; Zhengshan, J.; Guoru, W. Progress and prospect of ecological environment impact of land consolidation. Trans. Chin. Soc. Agric. Eng. 2011, S1, 340-345.

51. Thomas, J. Attempt on Systematization of Land Consolidation Approaches in Europe. ZFV Z. Fur Geodasie Geoinf. Und Landmanagement 2006, 161, 156-161.

52. Sklenicka, P. Applying evaluation criteria for the land consolidation effect to three contrasting study areas in the Czech Republic. Land Use Policy 2006, 23, 502-510. [CrossRef] 